\title{
考台地理学からみた響灘沿岸の砂質海岸の形成
}

\author{
小 野 忠 贸1

\section{Formation of the Sandy Coast of the Hibikinada from the Archaeolo-geographic point of view}

\author{
Tadahiro ONo ${ }^{11}$
}

In the case of the sandy coast of the Hibikinada, the west end of the mainland, I explicate in this report the process of the formation of bars and sand dunes mainly from the Archaeologeographic point of view.

1. The purposes of this report are as follows:

To correct the formative period of the diluvial old sand dunes.

To discover the bars formed by the Jomon transgression.

To add the data to infer the existence of little transgression of the middle of Yayoi age.

2. There are two pleistocene coastal sand dunes, one was formed before the Göttweiger interstadial. The other is Ayaragi old sand dune, which was before the Paudolf interstadial.

3. In Holocene bars piled at the transgressions of the earliest Jomon, the early Jomon, the first half of late Jomon, the middle Yayoi and the incipient stage of Heian age, and then exposed by each later regression.

Sand dunes were formed four times in Holocene; in the end of the earliest Jomon, in the second half of the late Jomon, from the end of the medieval ages to the middle of the modern ages and in the present age.

The first beach ridge was formed in the earliest Jomon, the second in the first half of late Jomon and the third in the incipient stage of Heian age. The new sand dune which give the topographical change is Tomito new sand dune, which was formed from the end of the medieval ages to the middle of the modern ages.

\section{はしがき}

ここに取りあげた響灘沿岸は，その占める地理的位置 坊本州の最西端にあたり，西に近く九州を控え，西南日 本の要の一部にあたる地域である。したがって，この地 域の砂質海岸の堆積過程を知ることは，西南日本の海浜 地形の発達史を知るうえの一つの助けになるであろう.

筆者は, 1950 年に潮待遺跡を発掘していらい, 砂浜遺 跡を含め，響灘沿岸で 10 遺跡の発掘調査を担当し，3 遺跡の調査に参加した. この間, 砂浜地形の形成時期に ついて若干の報告を重ねてきたのであったが，1965 年ご ろから，海岸段丘の珪砂を鋳物用として採掘する工事が 進捗し,これにとあなう人類遺跡の発掘調查が進展した。
このため, 古砂丘が断ら割られて切り下げられるなど, 砂堆や砂丘の断面を遺物や遺構と結びらけて観察する機 会が多くなり，地形発達史のうえで，空白になっていた 部分を補う新知見が相ついで添加し，從来の見解它固め ることができた一方，補正を必要とするものも生じてき た.したがって本稿では，新たな考古資料に拠って補訂 し, 本地域の砂浜堆積物の堆積過程を考古地理学の立場 から要記しておくことにした.

\section{I. 響灘沿岸の砂質海岸の概観}

1 ) 南高北低 本州島は, 東経 $130^{\circ} 54^{\prime}$ 付近で日本海 の一支海をなす響灘に没している．北の本場岬から彦島 の南端にいたる約 $93 \mathrm{~km}$ の海岸には，ほぼ中央に室津

1) 山口大学教育学部. Institute of Geography, Faculty of Education, Yamaguchi University. 


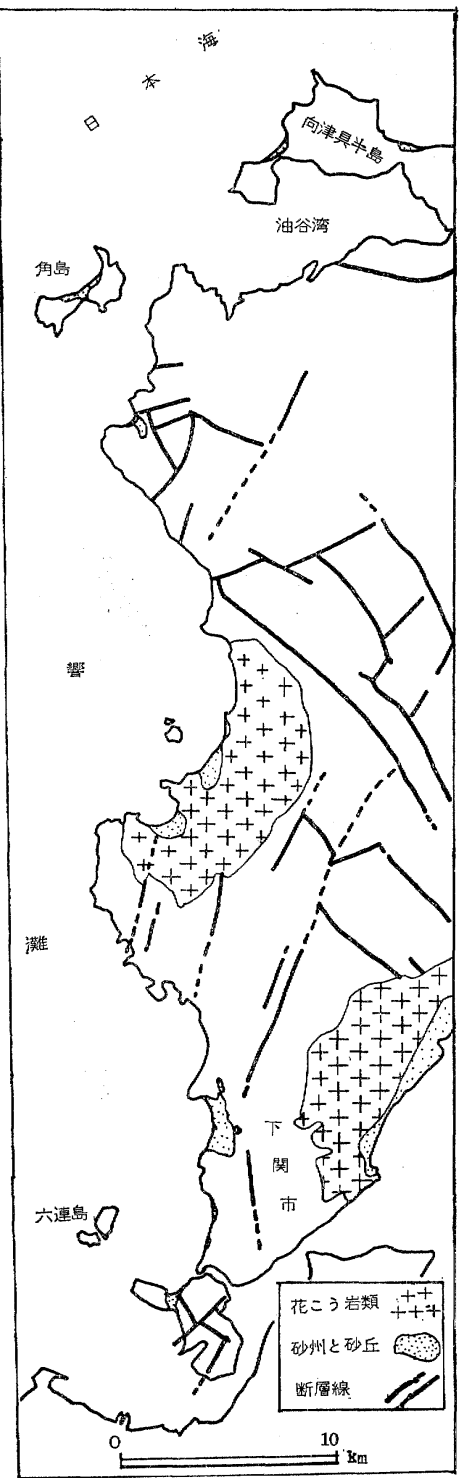

図 1 響灘沿岸の地体構造と花崗岩類および砂浜海 岸分布図（山口県地質図による）

半島が西にはり出し，北端の西に近く角島，南端に彦島 がある．地層（河野汸か，1975） は中生代白亜紀の脇野 亜層群と下関亚層群や花南岩類が多く, 中生代の玢岩類 や新生代第三紀の大辻層群と芦屋層群，第四紀の玄武岩 などが地形に変化を与えている. 北北東から南南西と， これに文交する北西から南東方向の断層線が走って地塊 群を形成し，地質の性質から，花崗岩地域を流れる諸河 川が砂砼を押し流し，川棚海岸や下関北部に砂質海岸を

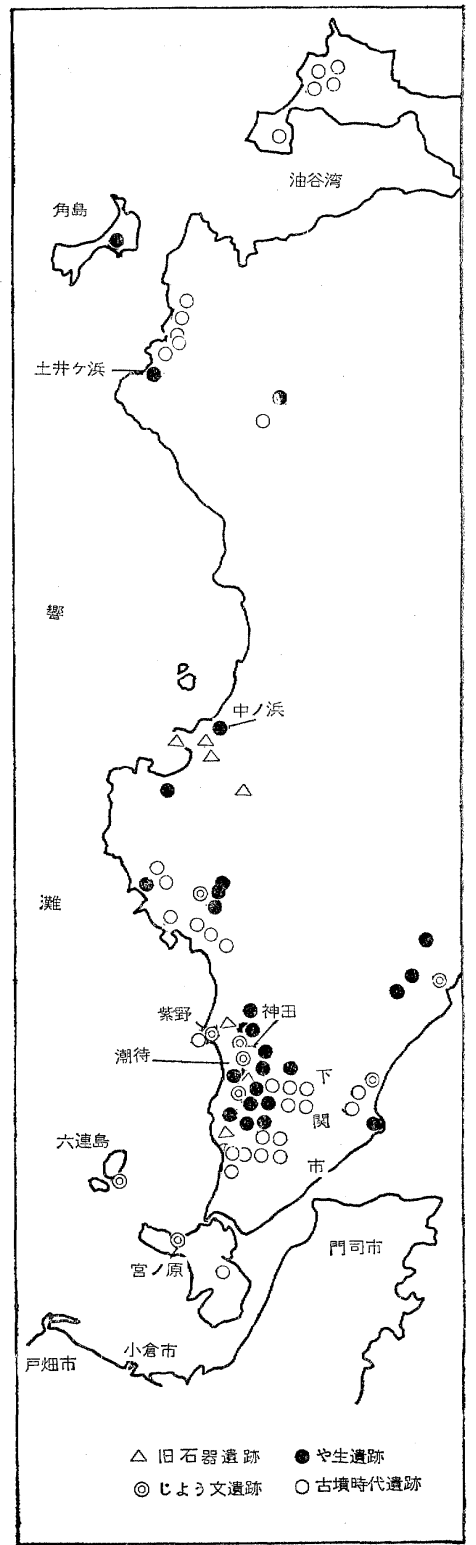

図 2 響灘沿岸の主要遺跡分布図

\section{くりひろげている.}

北進するにつれて沈水性の岩石海崖が多くなり，南進 するほど砂質海岸になる傾向を示し，砂州とともに砂丘 も局地的に発達して, 海岸段丘の高度とともに南高北低 の地盤運動定示唆している.

2）砂州と砂丘の分布 響灘沿岸の北東部は沈水した 岩石海岸で, 砂堆地形は極めてそしく, わずかに土井ケ 浜に浜堤と砂嘴の小砂堆があるにすぎない，角島の尾山 


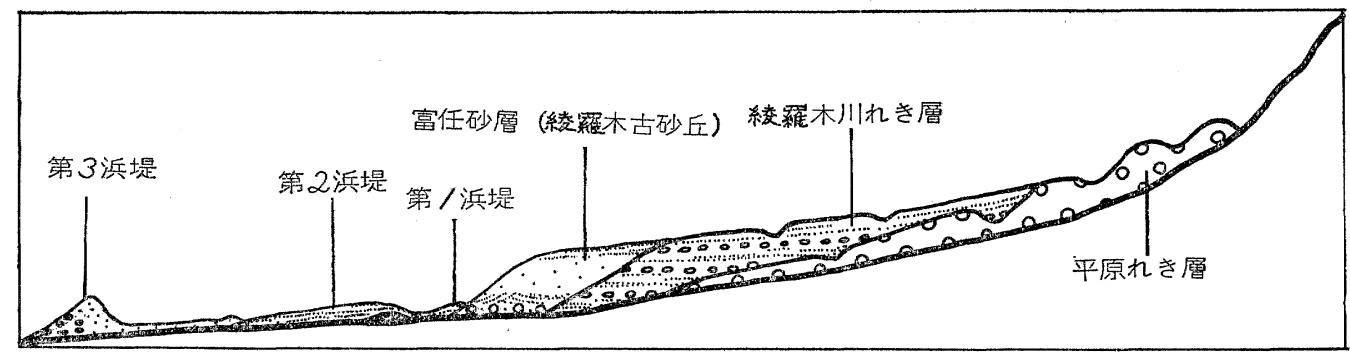

図 3 下関北郊安岡付近の海岸地形断面概念図 (1975. 8, 小野)

には，北西から吹きあげた砂が斜面をはいあがって，島 の頂上にも砂丘をつくっている.

川献川と室津川の川口の間には黒雲母花崗岩の青山丘 陵它はさえで田島と八ケ滨に 2 列の浜堤列が発達し，そ れぞれ飛砂が秥おう小砂丘を形成している。

下関付近では（亀山，1968)，吉見海岸や安岡海岸に ある 1 列の浜堤に集落がのり，花崗岩地域から流下する 綾羅木川の川口一带に 3 条の浜堤列がひろがって小海岸 平野を形成し，飛砂が背後の洪積台地にはいあがって砂 丘をつくっている。また, 彦島の老山山麓の西山には陸 繫砂州が発達し，飛砂が薄くお㧍うというように，響潅 の浴岸には, 花崗岩地域の分布や, 海底地形と地盤変動, 卓越する北西風などが相まって，小規模ではあるが浜堤 列と砂丘が分布している.

3) 人類の遺跡 響潅沿岸の砂丘地帯は，北九州とと もに人類遺跡の稠密地域で, 旧石器遺跡をはじめ, 繩文・ 弥生・古垻の各時代や有史時代の遺跡安数多く包蔵して いる. その分布は，浜堤列や洪積台地の多い中央部以南 の豊浦町や下関市域に集まり，北部には土并ヶ浜や沖田 遺跡のほかにほタるべきものがない，現在までにタつか っているおもな遺跡は, 旧石器遺跡 5 個所, 繩交遺跡 7 個所, 弥生遺跡 15 個所, 古墳時代遺跡 24 個所, 有史時 代のものも 21 個所它数え（山口県教委，1972），それら の多くが浜堤や洪積台地にあって砂堆や砂丘におおわれ ているものが多く, 砂浜地形の発達過程它知るうえに都 合のよい条件を提供している.

\section{II. 古砂丘の形成}

1 ) 安岡古砂丘 本地域には, 安岡半島と綾羅木川の 間に二つの時期の古砂丘がタらけられる. その一つは， 安岡半島の北東にある旧安岡中学校学のせていた安岡古 砂丘で，その高度が標高 $30 \mathrm{~m}$ 余りであった.

筆者は以前, この孤立丘化した安岡古砂丘が奴きんで て高く, 硬くしまった風成砂の層厚が $20 \mathrm{~m}$ にも達し,
しかも $3 \mathrm{~m}$ もある赤色風化殼が鮮かな赤色土 (7.5R 4/6 〜4/8) で厚いことから，中部洪積統に位置づけたこと があった（小野，1968a）。ところがその後, 安岡中学校 が移転し，古砂丘を切り下げて断ち割ったことから下部 の礫層を観察することができるようになり，この砂丘を のせる円䃯層が，クラストだけ風化した不完全風化磎で あることがわかった．その層位と層相から綾羅木川碍層 と同一時期のものであること岩知ることができたので， 上部洪積統の下部に当る時期 $(\mathrm{R} / \mathrm{W})$ に下げて位置づ けるのが妥当であると考えるようになった。

2 ) 綾羅木古砂丘 安岡海岸の東部一帯には, 風化䃋 層からなる平原硆層が蒲生野面をつくり, 標高 $30 \mathrm{~m}$ か ら $40 \mathrm{~m}$ の高度にひろがっている. 蒲生野面の前面には, ほぼ水平位に堆積した綾羅木川礫層が広く分布し，その 上部が赤色士化作用をうけている. 安岡古砂丘はこの綾 羅木川磁層の堆積の過程で形成された砂丘である、綾羅 木川砼層は，瀬戸内北岸の宇部砂磷互層に対比できる不 完全風化磁索をんだ円磯層からなるが，高度が標高 $10 \mathrm{~m}$ から $20 \mathrm{~m}$ ばかりなので, 同じ高度の滀任砂層（綾羅木 古砂丘）と区別できなかったため，両者を同時異相と考 えていた（河野·小野，1969）.

ところがそのご綾羅木郷台地が，珪砂の採掘と宅地造 成のために切り下げられたため，内部の構造を観察する ことができる機会をえた。 その結果，図3に示したよう に，綾羅木川礫層がつくる中位段丘の前面に，同じ高さ に富任砂層の一部をなす綾羅木古砂丘がおおい。との下 部に新鮮な旧海浜の円省層やラるナのある砂層があり, 瀬戸内の中位段丘の下位面に当る丸尾原面に対比できる ようになったので，雨者を異った二つの時期の堆積物や 地形面として訂正しておくここにした。また綾羅木占砂 丘の上部に緮羅木 I 交化とよぶ旧石器が，その古砂丘面 定覆う砂層中に綾羅木 II 交化と呼えだ細石器が出土し (小野，1958)，前者と同時期の横野（吉村，1965）や, 武久（宝川，1972）からも旧石器が出土している. 


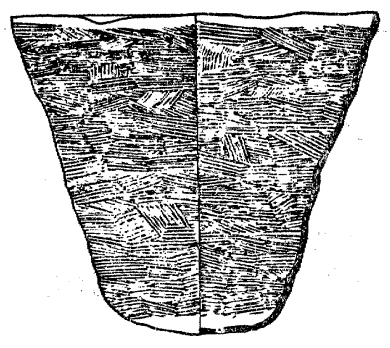

図 4 -梶栗浜遺跡の旧磷浜面にあった繩文早期の土 器（金関恕原図）

\section{III. 繩文時代の砂浜堆積物}

1) 繓文早期の砂磁浜 砂浜遺跡の発掘調查や, 珪砂 の採掘工事の機会に, 繩文早期末葉の砂浜堆積物をとら 光，当時の地形を推定することができた。

下関市安阊の梶栗浜遺跡では, 弥生墳墓の発掘中に, 海側に傾斜した碩浜に接して図 4 に示した繩文早期の琵 形土器が，落して割れた状態の穼を埋存している状況を 観察することができた.このことにより，早期の土器が 示す時代に，この円砅からなる南北方向にのびた碩浜 （図 5 (1)）が存在し，当時背後の洪積台地の侵食谷がラ グーンの状態であったと考えられ，沖積低地がほとえど 存在しなかったことを知ることができた。

彦島の宮ノ原遺跡A地点では，標高 $3.2 \mathrm{r}$ 内外の高さ に海進期の状態を示吉海側に傾斜した磁層と砂層の互層 があり，その上部の砂層中に繩文前期の古期の算畑式士 器をともなら一つの炉跡が，波浪で摇り恋げられながら 堆積していることがわかった（小野，1961a)，この事実 は，繩交前期の前半は間歇的な海進期で，それ以前にも 硆浜があったことを示し，これが梶栗浜の旧砂浜に対応 していることがわかったのである。

これらに対比することができる砂碩層は，山口市の美 濃ガ浜遺跡と宇部市の月崎遺跡（潮見，1968 a ）です見 ることができる，美濃ガ浜では，繩文前期の遺物学含む 海成砂層の下位に，この花崗岩の島には全くない結晶片

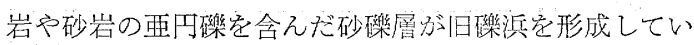
る (小野, 1961b).

これらの古い碩浜の分布は，洪積段丘の尖端付近や， 海岸のベンチにのっていて, 沖積低地が未発達であった ことを示している. 旧絔浜の高度は，現在の標高にして 梶栗浜で約 $2 \mathrm{~m}$ ，宮ノ原で約 $3 \mathrm{~m}$ ，月崎で約 $5 \mathrm{~m}$ ，美濃 ガ浜で沙 $3 \mathrm{~m}$ である。

2) 娓砂とクロスナ化 安岡半鼠の海岸段丘に繩文早 期の紫野遺跡 (小野, 1961c) 名あって, 往時の地表の 凹久や掘り込六穴に黑色の風成砂が充垻している.この 風成砂はさきに多た繩交早期の旧磁浜が形成される過程 か，その後間もないころ，北西風が吹き需げて生じた砂 丘砂であるが，薄層であったためその後削涂され，わず かに遺構の内部に残っていたと夕てよいであるう。

また東南に近い潮待貝塚のある洪積台地の台嘎の砂州 の下部に，この期に相当するとみられる薄い泥炭や黑色 のシルトや砂の堆積敩（図 5 (3)), 井戸を掘りあげた土 層の層序から指摘することができる、こ礼らの事実から 推して, 当时の気候は湿潤・冷涼で，植被もあり，砂丘

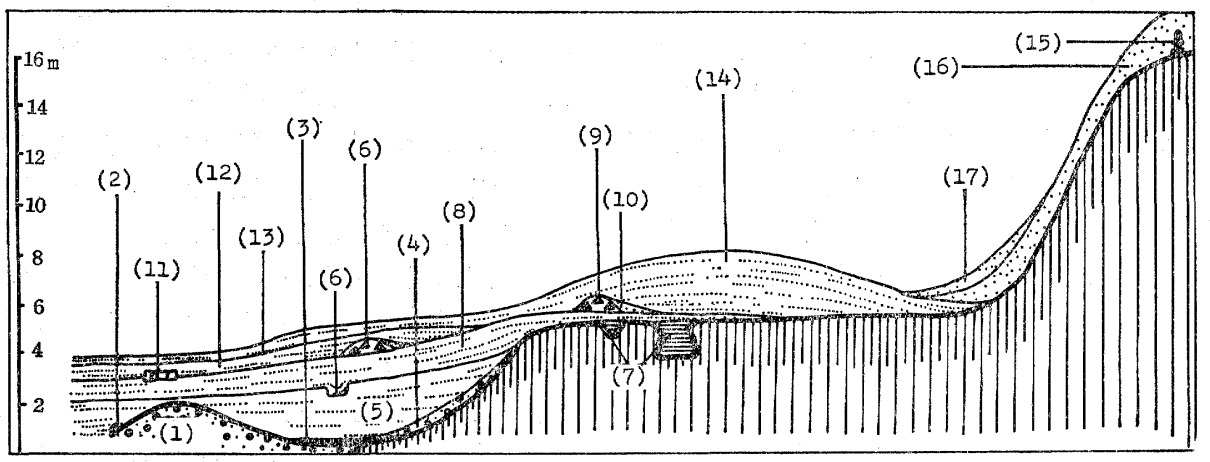

図 5 下関北郊潮待・神田両遗跡付近の砂浜の堆積過程説明図 (1975.2.15 小野)

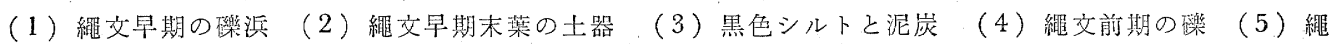

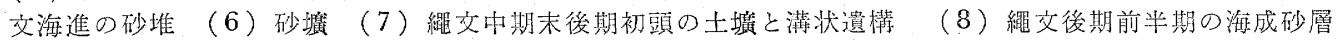
(9) 繩文後期後半の貝塚（10）繩文後期の砂丘砂（11）弥生前期未中期初頭の箱式石棺 (12) 弥生小海

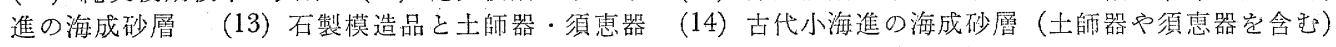
（15）中世の墳墓
(16) 近世の砂丘
(17) 現代の砂丘砂 
砂がクロスナ化したものと思われる。この期の小規模の 砂斥は, 京都府函石浜遺跡の東方や, 浜詰遗跡付近, 喜界 島の水天宮砂層, 下北半島のムシリ $\mathrm{B}$ 遺跡（䈎津, 1954) などにみられるもの之同時期のもののようである.

3) 縄交海進の砂堆 本地域をはじめ西日本では, 極 力さがし求めてきた汇もかかわらず，有楽町海進あるい は繩文海進とか子後水期海進とよばれる汎世界的な海進期 の堆積物がながい間みつからなかった，筆者は常々不思 議に思い，何度かこのことを指摘し，その理由が，地盤 変動の地域差にあるのではないかと考えたことが亦る。 ところがその後, 1970 年に下関市安岡所在の神田遺跡を 大規模に発掘する機会がおとずれ，このとき，繩文前期 の堆積物とみられる砂堆をとらえることができた（山口 県教委，1971）。すなおち, 遺跡のある地区には, 洪積台 地の末端が低く西に傾斜する斜面に匍行して堆積した䂺 層（図 5 (4)）薄くのり，その上部汇海成砂層が水平 位に堆積している.この砂層は一見上下一連の層に見光 るが，慎重に観察したところ，下位の兏白色砂層（図 5 (5)）と上位の茶褐色を带びた砂層（図 5 (8)）注不整合 で，その境界に人土とみられる 1 個の砂墴 (図 5 (6)) が あり, シイの果実がその底の床面や境界面に散らばった 状態で埋存し，この地面が繩交海進の極大期をすぎ，海 退に転じてからの生活面であったのではないかと考光る ようになったのである.

4 ）中期の海退と段丘上の遺整 下位の灰白色以下の 砂層に古期の曾畑式土器と轟式土器を含えでいるのに対 し, シイの果実の埋存面を覆う茶褐色砂層の下部には, 下位の兏白色砂層にみられない前期後半沉当る新期の曾 烟式土器と, 上部になるにつれて阿高式土器や船元式. 中津式など中期ふら後期初頭の土器を含み，この砂層の 堆積面に鐘ヶ崎式, 福田 $\mathrm{K}$ II 式なぞ後期中菜から後半の 土器定出す貝塚が築成されていることがわかった。

また近接した段丘面には口径と深さが $2 \mathrm{~m}$ も西る大形 土媛 (図 5 の (7)) が 9 個も群在し (山口県教委, 1971), この地から $200 \mathrm{~m}$ ぼかり南沉ある潮待遺跡でかってみ つかっていた，断面がV宇形の溝状遺構 (小野, 1961d) (図 5 の (7) ・ 図 6) が同じ層準に相当することから, 繩文前期の末から中期をへて後期初頭の間は海退してい て，洪積台地や前面の砂州が生活舞台になっていたこと がわかった。

近傍の潮待遗跡や彦島の宮/原遺跡と，周防灘北岸の 美濃ガ浜や月崎遗跡の海成砂層中から中期の阿高式土器 がみつかっており，西日本では繩交中期に海水準が相対 的に降下して汀線が後退し，居住空間が海側へひろがっ

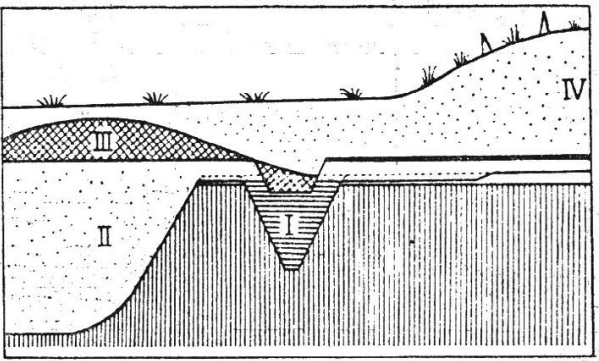

因 6 潮待貝塚 B 地点第 I トレンチ断面概念図 (小野原図)

I 帯青黑色粘土層一繩文中期末後初頭の遗物

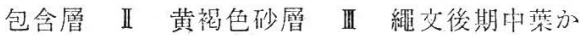
ら後半の貝塚 N 黄楊色砂層

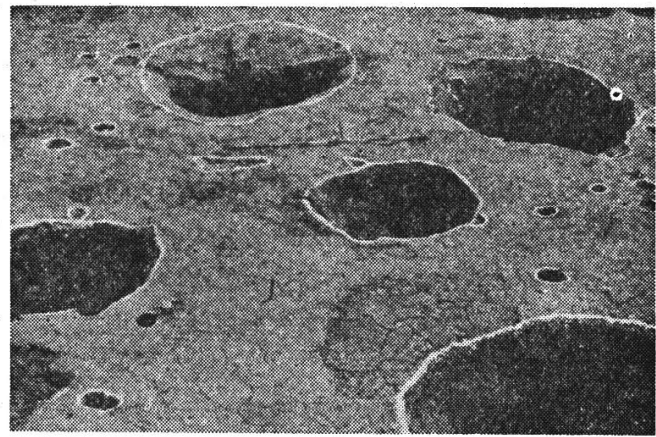

図 7 神田遺跡の繩文後期初頭の土拡群

(これらの土拡群は，繩交後期前半と古代小海 進時の海成砂層におおわれて埋存していた）

ていたことを予想していたが宮ノ原と神田や潮待遺跡で みつかった事実は，この推定䘮一層強化することができ た知見として重要である.

5 ) 後期前半の小海進とその眇堆 前項で触れたごと

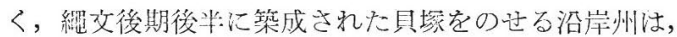
後期初頭以後, 後期後半のある时期以前の間の小海進に よって堆積したことを再確認することができた。この期 の小海准は寸でにしばしば指摘してきたとおりで（小 野，1963)，その際に形成された砂州の高さは，潮待や 神田では現在の標高で 5〜 5.45m, 宮ノ原遺跡の B . $\mathrm{C}$ 地点では海成層の高さが標高約 $6.6 \mathrm{~m}$, 美濃ガ浜で 7 $\mathrm{m}$ 内外，月崎遺跡では $8 \mathrm{~m}$ 余りである. 月崎遺跡には， 潮待 ·神田の両貝塚と 同一時期の生活面と炉跡があっ て，それらがその後の海進の波浪で擾乱された状態のま ま埋存していた（潮見，1968b).

この小海進によって堆皘した砂堆（図 5 の(8)）は， 細かく破砕されて磨滅した貝款粒が縞状に多く混入して 


\begin{tabular}{|c|c|c|c|c|c|c|c|c|c|}
\hline & 下部洪積世 & \multirow{2}{*}{$\begin{array}{c}\text { 中部洪積世 } \\
\text { 前期淐.石器時代 }\end{array}$} & 上部洪積世 & しょう文時代 & \multicolumn{2}{|c|}{ や生時代古僨時代 } & \multirow{2}{*}{ 中世 } & \multirow{2}{*}{ 近世 } & \multirow{2}{*}{ 近代現代 } \\
\hline & & & 中期旧石器時代 | & \begin{tabular}{l|l|l|l|l|l} 
早 & 前 & 中後 \\
\end{tabular} & 前中後前中後 & 古代 & & & \\
\hline $\begin{array}{l}\text { 海水隻 } \\
\text { 㲾動傾 }\end{array}$ & 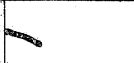 & & 後期旧石器時代 & & & & & & \\
\hline $\begin{array}{l}\text { 砂州の } \\
\text { 形成期 }\end{array}$ & 1 & & 23 & (1) 5 & (12) & (14) & & & \\
\hline $\begin{array}{l}\text { 眇兵の } \\
\text { 形成期 }\end{array}$ & 古砂丘I & & 古砂丘II 古砂丘III & $\begin{array}{|cc|}\text { 新砂丘I } & \text { 新砂丘II } \\
0 & (10)\end{array}$ & $\begin{array}{c}\text { 新砂丘IIIa } \\
\text { O }\end{array}$ & I砂丘I & & 蟼兵V & $\left.\right|_{\text {新砂丘I }}$ \\
\hline 砂乒の & & & & & ポク・方ロスオ & , & $\overline{a t}$ & & クロスナ \\
\hline
\end{tabular}

図 8 西日本の砂質海岸の形成期と海水準変動傾向曲線（）の数字は図 5 に照応

いる.この砂層は，梶栗浜では弥生前期末・中期初頭の 箱式石棺や石囲墓を（金関，1961），土井ケ浜遺跡では 200 体をこ光る弥生前期末葉の人骨学埋葬していた砂層 であって（金関・坪井·金関，1961），ともにこの小海 進のとき堆積した貝混りの砂層である.

このように本州の西端地方では，この繩文後期の小海 進によって，第 2 列目の沿岸州や陸繫砂州と砂嘴などの 砂浜地形方形成されたことがわかるのである. しかも特 に注意をひくことは，砂州の高さが繩文前期の後水期海 進のものよりも高いので，繩交前期の砂州を埋積してい て発見を困難にしている.

6) 末期の陸化と貝塚人の生活舞台 繩文時代の後期 後半から晚期にわたる繩文時代の末期には海退が進行 し, 後期前半の小海進によって堆積した砂州が露出して 陸化し，後期の後半に貝塚（図 5 の（9））がこの砂州の 上に営まれている.

この期の貝塚を発掘して調べると，貝殼の間や風下に 接して風成砂（図５の（10））が堆積し，海退の過程で飛 砂現象が起っていたことがわかり，この期の飛砂の堆積

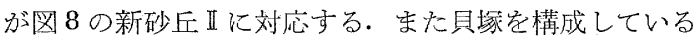
貝類は,・アサリ・ハマグリ・チョウセンハマグリ・オキ シジ・バイなどが多く, ヤマトシジミやミスジカワニ ナなど汽水棲や淡水産のものもみられるが，後に述べる ような弥生中期の貝塚に多い暖海椿のハイガイや高虚水 産のマガキ注全く見当らない(小野，1961e).

海退による陸化は汀線を後退せしめ，繩交晚期から弥 生前期のころには低地帯に水田可耕地を出現したものと 推察することができる.この期の低地遺跡には，全国的 に, 薄い泥炭や黑色粘土とシルトが堆積し（藤，1966）, 西日本の標高 $400 \mathrm{~m}$ 以上の山地にクロボクをのこして おり (小野, 1970)，当時の気候が湿潤で泠涼だったこ とを物語っている.

潮待や神田の貝塚人は前面の海域で漁撈を行い，イノ
シシやシカなどの獣骨とイヌの骨があるところから狩猟 も営夕, 石皿と磨石や, 弥生前期や中期に似たV字潭と 大形土塯群の存在汸, 繩交後期に原始陸耕が行われてい たこと宗唆している。

\section{IV. 弥生時代以後の砂浜堆積物}

1 ) 弥生前期の小海退 稲作農耕が渡来した繩文晚期 や，それが地域的に展開しはじめた弥生前期の海退現象 は次の事実から指摘することができる。

（1）下関市の西北方約 $5.5 \mathrm{~km}$ の海上にある繩交晚 期の六連島遺跡は，六連島西南端の砂嘴に立地するが， 包含層は標高 $2.5 \sim 3.5 \mathrm{~m}$ で，形成後波浪の擾乱をうけ たのち埋没している（小野，1961 e).

（2）弥生前期の綾羅木郷（金関·国分，1966）・伊 倉（山口県教委, $1973 \mathrm{a}$ ) ·など巨大な農耕集落の遺跡 が，いずれも海浜に近い台麓の低湿地を抱いた低位の洪 積台地に立地している。

（3）弥生前期の中浜遺跡と土井ヶ浜遺跡や, 前期末 中期初頭の梶栗浜遺跡など著名な原始墳墓が，繩文後期 の前半に堆積したのち海退して陸化した，第 2 浜堤内側 の標高 $3 \mathrm{~m}$ 内外の高さに営まれている.

（4）対岸の遠賀川流域にある弥生前期の立屋敷遺跡 が，遠賀川の河床下に埋没しているところから推して， 当時水位が低く，陸化していたこと穵物語っていること などをあげることができる。

華中で気候に順化した栽培稲であるとはいえ（永井， 1959)，业熱寡原産の稲を作る農耕村落が，今日よりも 冷涼であった日本列島へ進出して定着し, 大きな村落を 維持しえた原因の一つは，わずかではあるが海水準が下 り, 河畔や海浜の低地に, 直播可能な水田可耕地が生じ たためと思われる。

2) 弥生小海進 弥生時代の中期か後期のころ, 小海 進の傾向が見られることは早くから知られ，その発現期 


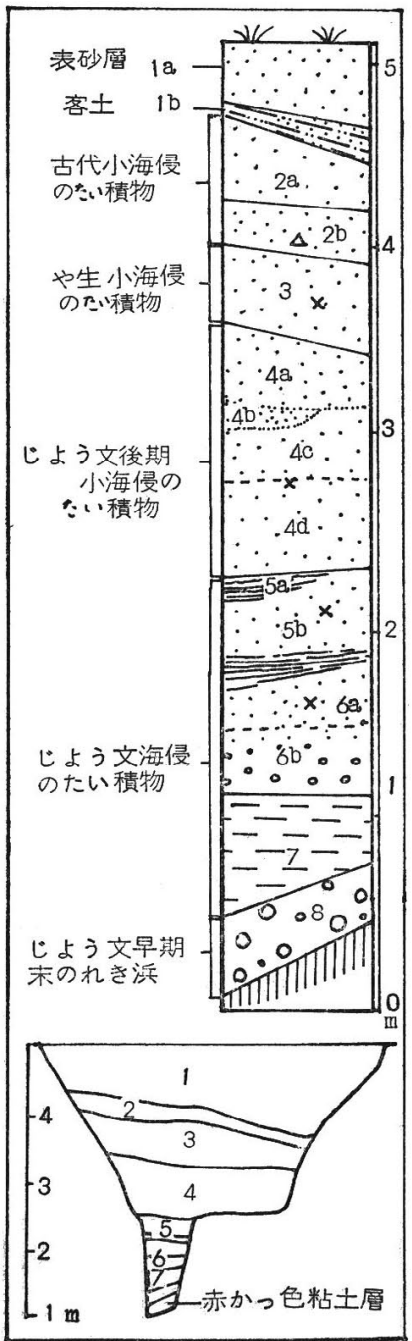

図 9 神田遺跡 $\mathrm{H}$ 区の砂堆断面説明図

( $\times$ 印は土器, $\triangle$ 印は石製模造品や土師器と須 恵器の出土層準) 下の図はダリッドの断面

や変動量に地域差があることも指摘されていた（中野 · 1956 ; 井関, 1968 - 1974). 筆者は本州西端部で，この 期の海浜堆積物に関する資料の検出につとめてきた。堂 ノ尾, 鎧, 北迫 (直良, 1968), 引野，中郷などの諸遺 跡にみる暖海棲のハイガイと筬水産のマガキを主とした 小貝塚や, 海浜加ら遠い丘陵の頂の高地性貝塚 (小野, 1968b） の存在から，海水温と海水準の上昇を示唆する 傍証的な知見を得たのであったが，海浜の砂堆は次期の 海成層の底に埋没し，しかも波浪の作用によって擾乱さ れていて，弥生時代の海成の砂堆であることを示す概括

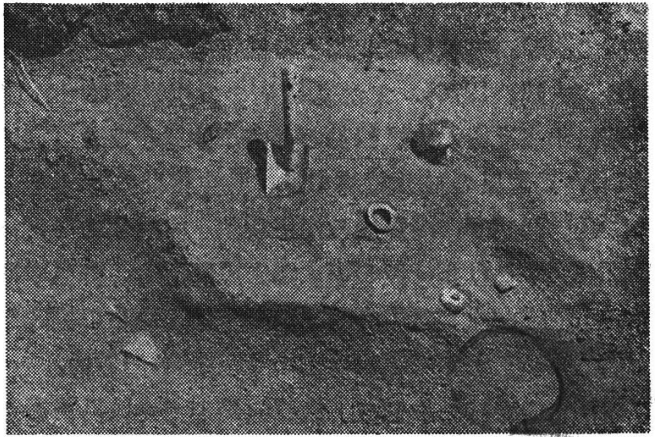

図 10 神田遺跡の石製模造品の出土状況

的な考古地理的資料しかつかめなかった（小野・本村， 1968c).

ところが先述のごとく，神思遺跡で 5 回にわたって広 い区域を発掘する機会をえ, 弥生時代とみられる海浜堆 積物定とら元, 空白の一部を埋めることができた、神田 遺跡の $\mathrm{A}$ 区と $\mathrm{H}$ 区の発掘中, 繩文後期の貝塚を覆う砂層 が連続する旧地形面で，剣形・鏡形扔よび釧形の滑石製 の石製模造品が，まとまって埋存している状態をつきと めた（山口県教委，1972). 石製模造品をのせる海成砂 層はA区では標高 $4.3 \mathrm{~m}$ ばかりで低く，鐘ケ崎式・福 田 $\mathrm{K}$ II 式や津雲 $\mathrm{A}$ 式土器などの繩文式土器を含み, その 層厚がH区で約 $45 \mathrm{~cm}$ であった.

またこの種の石製模造品は，本地方では 6 世紀から 7 世紀の間に相当する古墳時代後期の古代製塩址（近藤, 1968）に共伴するところから推して，これらをのせる海 成砂層が, 最大限, 繩文後期の末から古墳時代の後期の 間に生じた小海進によって堆積した砂州であることがわ かったのである.

この堆積の時期をもっとしぼると, 次のように指摘す ることができる，貝塚が廃墟になった繩文後期から弥生 時代の前期の時期は, 先述のように小海退期で，時代的 下限它示す古墳時代もクロボクや黑色シルトぶ推積した 海水準の低下期であり，一方，ハイガイとマガキを主体 とする貝塚の出現期が, 弥生時代の中期から後期初頭の 間に限られていることから推して，このころをピークに 海浜地形にほとえど痕跡をとどめないていどの小海進が あったことが考えられるのである。

このような弥生中期の小海進は, 次のような諸事象か らも察知することができる.すなわち伊東信雄による 上, 柬北地方にはじめて稲作が波及したのが弥生中期で, 今日で稲作が不安定な青森県の内陸部にまで達し（石 田ほか，1968)，このころ気候が暖化していたことを示 唆しており, 吉崎昌一は, その後 $5 \cdot 6$ 世紀には冷涼化 
乙て稲作前線が一時期後退し, 北海道から続紆文文化圈 の南の限界が宮城県の北部まで南下したことを指摘して いる(吉崎, 1974)。 をた大阪府の瓜生堂遗跡では弥生 中期に小海進を示す堆積物の存在が注意をひき（安田, 1973), 鳥取県の白鬼海岸では, 弥生後期の土器を含む 小砂丘の形成が, 海進後の海退現象家示唆するなど（豊 島, 1975), これら一連の事象がよく照応し, 弥生中期後 半に小海進が生じたであらうという以前からの推定を一 層強化することができたのである（小野，1975).

3 ）古填時代の小海退 本州西端地方では，次のよう な資料から，古墳時代の前半が海退期で冷涼であり，そ のご平安初期にか沙て間歇的にしかも徐々に海准が進え だため，この間の時代は海水準が低かったようである. 響漢沿岸では, 古式土師器を出土する土井ヶ浜遗跡の砂 浜の上層や，上記の神田遗跡の石製模造品の出土地点か ら知られるが, 周防灘北岸では当時の海浜堆積物を適切 に説明することができる知見が多い。

もっともよい例は，宇部市東岐波の波雁方浜遗跡であ る, この地では, 古代製塩址の炉址や製塩土器の層位的 な発達の実態から, 標高 $9 \mathrm{~m}$ の第 3 浜堤の主体部が古墳 時代後半からの海面の上昇によって形成されたとと宗 している (小野, 1968d). また美濃ガ浜遺跡で法, 現在 の満潮界の汀線すれすれの旧海底面に夥しい死貝を含虫 砂磪層がひろがり，その上位に堆積した砂滦層の中に土 師器の包含層や， 3 層の炉址とともに進化した製壏土器 の存在が，当時今日より水位が低かったこと窟物語って いる・德山市の老郷地遺跡でみるように, 古式土師器を 出土する住居地の床面を面接覆ったクロボクや（小野， 同地の岡原古境では，後期古境の封土の底の汇地表面に 1969), クロボクが堆積しているという事実（山口県教 委，1970）が，前項でしるした束北地方の父候の泠涼化 と照応しこのころやや泠涼であったことがわかるので ある。

4) 古代小海進 この期の海進は見かけ上，本地方の 沖積世で最も大きく，現在の汀線汇近い第3 浜堤を形成 している，その高度は地域によって異なるが，低い方で 防府市鞠生松原の約 $4 \cdot 5 \mathrm{~m}$, 高いもので宇部市波雁ガ 浜の $9 \mathrm{~m}$ である. 安岡海岸では $5 \mathrm{~m}$ 内外をはかり, 第 2 浜堤をこ光て第 1 浜堤につづく低位の洪積台地にまで堆 積し, 潮待と神田の雨遗跡付近では, 繩文後期後半の具 塚や，弥生時代の砂堆穵おおい，標高が $8 \mathrm{~m}$ ，炎の層厚 は $2 \mathrm{~m}$ に達している．遺跡付近では，海進により，それ 以前の遺物を波浪が摆りあげながら須恵器や土脰器と石 製模造品を含む砂堆を形成し，微量の貝款を含芑砂層も
あって, 層序や交化遺物から形成のメカニズムや堆積の 時期がとら党やすい。

このほか, 平安前期の洪水の頻発や浸水による国府の 移転現象もまた有力な傍証の一つである（木下，1975）。

5 ) 中世の小海退と新砂丘中世の小海退が原因にな って発達した中世末期いごの新砂丘は 2 期に分けられ， 中世末期から近世にかけて形成された巨大な砂丘を新砂 丘 $\mathrm{V} \mathrm{a}$ ，明治中葉以降の飛砂による砂丘を新砂丘 $\mathrm{Nb}$ と よえでいる (小野, 1969)。歴史時代の古気候の永年変化 の研究によると，15世紀前半に冷涼期の極大を示してい る（山本，1974）。西日本にはこれと対応すると見られ る小海退があって広大な干潟が出現し，巨大な新砂丘の 形成をみた一方，近世の大規模な干拓新田が造成せられ た（小野，1962）。この一連の自然・人交の両分野にみ る大きな変貌は沉世界的で（藤岡，1970），その遠因が， 中世の小海退に関連する自然環境の変化にあったと考え られる、響淎沿岸では，安岡海岸の東に連なる䈏往の洪 積台地には，中世の七辻古墓 (図 11) 空新砂丘 $\mathbb{N a}$ （図 5 (16)）が扮うている（吉村，1964）。乙の中世の古墓 は鎌會時代汃ら室町町代の間に造営されたものと推測さ れ，当時は洪積層の赤色土が露出した状態であったが， この古墓の埋葬孕断たれたころか，それ以後のある時期 から飛砂が激しくなり，遂に，厚さが $2 \mathrm{~m}$ にも達する新 砂丘砂にお扮われて埋没した。 この事実から推して，中 世小海退の極大期は室町期かそれにつづくころと推定さ れるので, 新砂丘の形成は鳥取砂丘と同様 (大西・伊藤,

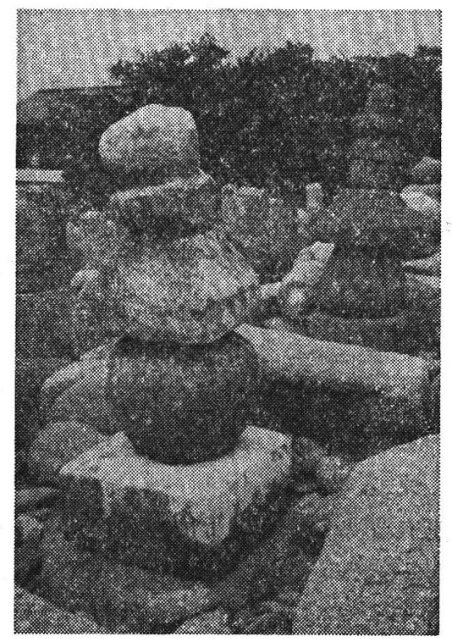

図11 下関市富任七辻の新砂丘に埋没していた中 世の古墓. 写真は採仯のため移転してから 後の状沉. (吉村次郎提供) 


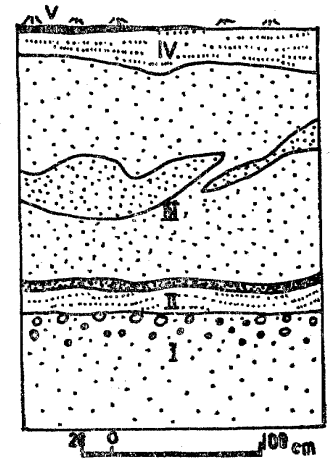

図 12 宮/原遗跡，B地点断面実測図 (小野原図) I 含浮石褐色砂層 II 淡黄白色砂層 III 摚乱 砂層 $\mathrm{N}$ 兏白色砂層 $\mathrm{V}$ 含腐植黒色砂層

1960) このころ以後ということになる. 山陰の砂丘（豊 島・赤木，1964）や吹上浜砂丘など（成瀬，1969，角田， 1973)，巨大な新砂丘に相当する響潅沿岸の IV a 期の砂 丘は, 沖積世に形成された沿岸州の砂を供給源として発 達している.しかし響灘の沿岸では大きな河川がなく， 山地方らの砂の供給が少ないうえに隆起量も少ないの で，風成砂丘の規模が小さい.この期の新砂丘は，北か ら角島の尾山砂丘, 八ケ浜砂丘, 富任砂丘, 宮ノ原砂 丘, 芦屋砂丘（角田，1972）なぞがある. 芦屋付近には 古砂丘が発達しているが新砂丘の発達が苾く, 飛砂が薄 く古砂丘を被覆しているにすぎない。

6) 現代の飛砂現象とクロスナ化 近世後期には浜堤 に防風林や防砂林が植林され，移動砂丘が固定化したが， 明治中葉から再び 飛砂がはじまって新砂丘 V b をつく った.しかし，我砂防止の施設や砂丘地の積極的な農地 開発によって抑止され，今日では固定砂丘になり，裸地 で強風時に飛砂現象がみられる程度である.

図 12 浐島の宮, 原遺跡 $\mathrm{B}$ 地点の断面図である. 図 のII の學乱層は左鄉軍人徽章它包含しており, 現代に なって他の場所で廃棄された土砂と一諸に盛りあげたも ので，この運搬土砂の層の上位に堆積したNの砂層はご く新しい現代の風成層である。た $\mathbb{V}$ 層の上位には厚さ $10 \mathrm{~cm}$ ばかりの新鮮なクロスナ層が形成されており, 最 近，クロスナ化完促す自然環境下にあること家唆し， このような現代のクロスナの存在は, 偏西風波動帯の乱 れといわれる寒冷化現象（福井，1973）と照忘する知見 として注意气ひく.

\section{V. 響灘沿岸の砂質海岸形成の特質}

\section{1) 形成過程の要約}

认上, 考古地理資料に拠って, 本州西端の響濉東岸を
対象に, 第四紀, とくに沖積世の海成層と風成層の堆積 過程をのべてきた. ここで要約するとともに，本地域の もつ特質学摘記しておくことにする.

（1）海岸の基盤面に堆積した村崎粘土層と平原碩層 のう方, 前者を下部洪積統に位置づけ, 後者は一応中部 洪積統におかれているが，確定は保留されている.上部 洪積統の綾羅木川磞層と富任砂層を同時異相とされてき たが，両層は堆積の時期を異にする別個の地層であるこ とが明らかになった。また安岡古砂丘は綾羅木川䃋層中 の砂丘で, 綾羅木古砂丘は富任砂層と同時期の砂丘であ ることがわかってきた。

(2) 綾羅木川川口付近の安岡海岸では, 図 5 に示し たような沖積世の沿岸州と新砂丘の堆積過程を指摘する ことができる. このうち, 同図 (5) の繩交海進と, (12) の弥生小海進と推定される砂堆の存在を神田遺跡 でも析出することができた。

（3）安岡半島北西縁の汀線にある泥炭は，花粉分析 による畑中健一の研究がある（畑中，1966). これによ ると温暖期の植物化石層からなり，繩文海進によって生 ごた浅海性の大江堆積物とされている.この泥炭層を 図 5 の砂堆に結びつけると，(5) の砂州面に散在する シイの果実の地形面の延長に位置づけられるようであ る.

（4）沖積世の砂州は，繩文早期，繩交前期，繩文後 期前半, 弥生中期末葉, 平安時代初期の々れぞれの海進 の際に堆積し，それぞれの後の海退によって露出した地 形面に堆積した。飛砂現象による砂丘の形成は，繩交早 期の末と繩文後期後半や，中世の末から近世前半の間お よび明治末年から以後の現代である。

このうらおもな浜堤を形成した砂州は，第 1 浜堤が繩 文早期, 第 2 期浜堤は繩文後期前半, 第 3 期浜堤は平安 初期に堆積した砂州で, 地形に变化を与えるような新砂 丘は，中世の末から近世の前半の間に形成された富任新 砂丘である.

（5）砂堆や砂丘の形成時期と，クロボクやクロスナ の形成期との関連から, 図8 亿示した相対的海水準变動 傾向曲線を描くことができる。

\section{2) 響灘沿岸の砂浜形成の特翼}

（1）との第1 は，ながい間本州最西端の海岸地带で は, 後水期のらちでもっとも顕著といわれる名後水期海進 の堆積物がみつからなかったことからもわかるよらに， この期の砂堆の発達が弱いことである. しか子海進時の 海水準の高度が見かけじょう低く，そのごの 2 回の海進 堆積物におおわ持埋没してタつかりにくく東日本と刘蹠 
的である(多田，1964；江坂，1965；遠藤，1967；阪口， 1968). この現象は, 西南日本が, 東海陸地とよばれた東 シナ海の沿岸地带にみられる後水期の沈水海岸の一部を なし, 日本列島の東高西低的造地形運動との関連を示唆 する現象ともタることができよう。

（2）こえにちの砂質海岸を形成している砂堆地形は 二つある. このうちもっともよく発達しているのは, 古 墳時代の後半から平安初期にかけて間歇的に堆積してい った古代小海進の砂州であって, これが現在のビーチの 浜堤を形成している. これについで大きいのは繩交後期 小海進の砂州であり, そのごの海退期に姿をあらわした 浜堤の上に, 後期後半の貝塚や弥生前期から中期前半に かけての原始墓が造営されている.

（3）砂浜に遺存する考古地理資料からみた限りで は, 先史時代に, 北浦海岸は総じて沈水傾向を, 響灘東 岸は南高北低的地盤变動を示し, 西瀬戸内北岸では安芸 灘を中心とする造盆地運動（桑代，1959）と, 宇部付近 の離水現象 (小野, 1968e) がタうけられ，この傾向は 有史時代も続いていて（山口県教委，1973）, 本地方の 砂質海岸の形成のう光に基礎的影響を与えている.

\section{む す び}

遺跡や遺物など，人類の遺構や遺品を文化的示準化石 として土地・地域に結びつけ，時間と空間の接点から海 浜地形の变遷史を組みあげる考古地理学の浛あい, 資料 のもつ性質や方法論上の得失をよくわきをえておか子小゙ ならない。

考古資料や考古地理的知見は，砂質海岸の堆積物の相 対的年代を決めるうえで有効な方法である. しかし仮り に，砂浜の箱式石棺から紀年鏡や銭貨が出土したとして も, 砂堆や砂丘が堆積した敩密な意味での正確な実年代 をとらえることは至難である.しかも海浜地形は風浪に よる擾乱作用をらけるので, ${ }^{14} \mathrm{C}$ 法や地磁気年代学的方 法の対象にもなり難い, したがって海崖の崩落とか, 土 木工事や発掘調査のような特別な事情が起らない限り採 取しにくい性質のものなので，気永な継続的観察を行な い, 資料觉呤味して考察を進め, 確かな知見を添加しな がら相対的編年の補正它重ねる努力が要請せられるので ある・

\section{引用 交 献}

江坂輝弥 (1965) 繩交時代の生活の舞台.日本の考古学, II, 河出畫房, 473p. ; 399-408.

遠藤邦彦 (1967) 日本海沿岸の過去 2 万年間の海水準変 化. 考古学ジャーナル，3，8-9.
藤 則雄 (1966) 日本に打ける後氷期の気候变遷. 第四 紀研究， 5，150-155.

藤岡謙二郎 (1970) 人文地理学. 大明堂, 271 p., 78 . 福井英一郎 (1973) 日本に扮ける最近の低温化の傾向と その動的考察. 地理評, 46, 231-240.

畑中健一 (1966) 山口県安岡付近の第四紀堆積物の花粉 分析. 考古学研究, 13, 34.

石田英一郎 - 泉 靖一 - 有光教一 - 伊東信雄 - 金廷鶴 芹沢長介・宋交薰・坪井清足 (1968) シンポジューム 日本農耕交化の起源. 角川新書， 210 p. ; 64-69.

井関弘太郎 (1968) 先史時代・歴史時代の地殸变動. 第 四紀研究，7，127-130.

井関弘太郎 (1974) 日本に打ける 2,000 年 B.P. ころ の海水準. 名古屋大学交学部研究論集 LXII 抜刷. $162-163$.

桑代 勲 (1959) 瀬戸内海の海底地形. 地理評， 32, $24-34$.

金関丈夫・坪井清足・金関 恕 (1961) 山口祘土井浜遺 跡. 日本農耕交化の生成，東京堂，376 p. ; 223 253.

金関丈夫・国分直一（1966）下関市綾羅木郷台地遺跡発 掘調査概報. 下関市教育委員会, (15).

金関 㤎 (1961) 梶栗浜遗跡. 山口県交化財概要，第 4 集, 山口県教育委員会, $144 \mathrm{p} . ; 59-65$.

㿝山德彦 (1968) 関門地方の第四系. 地質雑，74，415426.

河野通弘・小野忠㜯（1969）中国地方西部の第四系. 日 本の第四系, 地学団体研究会, 433p. ; 381.

河野通弘 ·岡村義彦 · 三上貴彦 - 西村祐二郎 - 高橋英太 郎 (1975) 山口県地質図. 山口地学会.

近藤義郎 (1968) 宇部市波雁ガ浜遺跡について．宇部の 遺跡，279p.；244-252.

木下 良 (1975) 災害による国府の移転. 歴史地理学会 会報， $(81) ， 25-26$.

永井威三郎 (1959) 米の歴史. 至交堂, 250 p. ; 63-98. 中野尊正 (1956) 日本の平野. 古今書院，309 p. ; 95185.

直良信夫 (1968) 宇部市北迫遺跡の自然遺物. 宇部の遺 跡，279 p. ; 232-237.

成瀬敏郎 (1969) 鹿児島県吹上浜砂丘の地形. 地理科学, 12, $48-57$.

大西正己・伊藤正史（1960）砂丘の生いた台，大明堂， 268 p. ; 68-76.

小野忠熙 (1958) 山口県下関市稜羅木弥生遺跡，考古学 雑，43，235-249.

小野忠熙 (1961a) 宮ノ原遺跡. 山口県交化財概要，第 4 集, 144 p. ; 42-46.

小野忠潶 (1961b) 美濃ガ浜遗跡. 山口県交化財概要, 第 4 集, 144 p. ; 41-43.

小野忠溤 (1961c) 紫野遺跡. 山口県交化財概要, 第 4 集, 144 p. ; 71-75.

小野忠熙 (1961d) 潮待貝塚. 山口県文化財概要，第 4 集， 144 p. ; 69-70.

小野忠熙 (1961e) 六連島遺跡. 山口県文化財概要, 第 4 集, 144 p. ; 47 . 
小野忠熙 (1962) 新田成立の自然的基礎. 地理科学, 2, $1-6$.

小野忠熙 (1963) 本州西端地方にお汀る海岸砂丘の形成 期の研究. 地理評, 36, 391-410.

小野忠菣 (1968a) 考古地理学からみた 海岸砂丘の形成 時期と諸問題. 日本地理学会シンポジューム資料, $1-9$.

小野忠漶 $(1968$ b ) 宇部市北迫遺跡と高地性貝塚集落の

問題. 宇部の遺跡, 279 p. ; 223-231.

小野忠㜯 $(1968 \mathrm{c})$ 砂堆の構造と堆積過程. 宇部の遺 跡, 279 p. ; 119-120.

小野忠㜯 (1968d) 第四紀の宇部の海岸地形. 宇部の遺 跡， 279 p. ; 256-2666.

小野忠㜯 (1969) 老郷地遗跡. 德山市教育委員会 20 p. ; 5-10.

小野忠㜯 (1969) 考古地理学からみた海岸平野の形成 一本州西端地方一. 日本地質学会第 76 年学術大会シ ンポジウム「海岸平野」資料集，159-164.

小野忠㜯 (1970) 本州西端部の黑土の成因と生成時期.

腐植年代学に関する総合研究，資源研，66-69.

小野忠㜯 (1975) 弥生時代の砂浜海岸と人文生態, 地理, 20, 12.

小野忠喣·本村豪章 (1968) 波雁ガ浜遺跡. 宇部の遺 跡, 279 p. ; 116-135.

笹津備洋 (1954) 青森県下北郡吹切沢遺跡. 日本考古学 年報, 7, 214 p. ; 34 .

阪口 豊(1968) 沖積世に打ける関東平野中央部の陸化 期の年代. 第四紀研究，7，57-58.

潮見 浩 (1968a) 月㥓遺跡, 宇部の遺跡, 279 p. ; 38 70 .

笹津備洋 (1968b) 同上. 27.

角田清美 (1972) 芦屋町の自然の生いた方. 芦屋町誌, $18,6-17$.

角田清美 (1973) 鹿児島県・吹上浜眇丘の地形につい
て. 駒沢地理, 9, 117-123.

多田交男 (1964) 自然環境の变貌. 東京大学出版会, 282 p. ; 226-229.

宝川昭男 (1972) 下関市武久町の洪積世層出土尖頭器. 考古学ジャーナル，7，19-21.

豊島吉則 (1975) 日本海岸の砂丘. 日本第四紀学会昭和 49 年度シンポジニーム資料.

豊島吉則・赤木三郎 (1964) 気高町宝木高浜砂丘の形成 について. 鳥取大学学芸学部研究紀要, 15, 12-20.

和島誠一 ·麻生優 - 田中義明 (1964) 北九州に抢ける後 氷期の海進・海退について. 資源研彙報 (63), 6472.

山口県教育委員会編（1970）山口県德山市久米岡原古墳 発掘調查概要. 德山市教育委員会, 18 p. ; 6 .

山口県教育委員会編 (1971) 神田遺跡第一次発掘調查概 報. 25 p. ; 5-12.

山口県教育委員会編 (1972) 山口県遺跡分布図. 山口県 教育委員会.

山口県教育委員会編 (1972) 神田遺跡第二次発掘調查概 報. 15 p. ; 8-14.

山口県教育委員会編 $(1973 \mathrm{a}$ ) 伊倉遺跡. 山口県教育委 員会, 109 p. ; 108-109.

山口県教育委員会編 $(1973 \mathrm{~b})$ 柳井市与浦遺跡. 下関市 神田遺跡発掘調查概報. 32 p. ; 12.

安田喜憲(1973) 瓜生堂遺跡の泥土の花粉分析. 瓜生堂 遺跡, II, 瓜生堂遺跡調査会. 104 p. ; 76-102.

山本武夫 (1974) 日本の気候変動と沖積世の寒冷気候. 第四紀研究，12，155-158.

吉村次郎 (1964) 七辻古墓 埋蔵交化財包藏地調査カー ド. 下関市教育委員会,

吉村次郎 (1965) 原始 - 古代. 下関市史原始一中世, 83-87.

吉崎昌一 (1974) 北辺文化の变遷. 講談社, 164 p. ; 102 -103 . 